\title{
The use of Artificial Neural Networks in the diagnosis of manageable factors on Brazilian Primary Health Care
}

O uso de Redes Neurais Artificiais no diagnóstico de fatores gerenciáveis na Atenção Primária à Saúde no Brasil

El uso de Redes Neuronales Artificiales en el diagnóstico de factores de gestión en Atención Primaria de Salud en Brasil

Received: 01/07/2021 | Reviewed: 01/08/2021 | Accept: 01/13/2021 | Published: 01/17/2021

Kerla Fabiana Dias Cabral

ORCID: https://orcid.org/0000-0003-1218-935X Universidade Federal de Viçosa, Brazil

E-mail: kerlacabral@hotmail.com

Fábio Ribeiro Cerqueira

ORCID: https://orcid.org/0000-0002-3661-1570 Universidade Federal de Viçosa, Brazil

E-mail: frcerqueira@gmail.com

Rodrigo Siqueira-Batista

ORCID: https://orcid.org/0000-0002-3661-1570 Universidade Federal de Viçosa, Brazil E-mail: rsiqueirabatista@yahoo.com.br

Marco Aurélio Marques Ferreira

ORCID: https://orcid.org/0000-0002-9538-1699 Universidade Federal de Viçosa, Brazil E-mail: marcoufv1@gmail.com

Bruna Rodrigues de Freitas

ORCID: https://orcid.org/0000-0003-0512-4240 Instituto Federal de Educação Ciência e Tecnologia do Sudeste de Minas Gerais, Brazil E-mail: brunet.rodrigues@hotmail.com

\begin{abstract}
The social determinants of health are relevant in the main strategies of Primary Health Care. However, it is known the difficulties of the health sector to overcome the factors that negatively interfere with the health of the population. Thus, it was aimed to create a computer model to present in detail the factors that somehow are related to the Primary Health Care, enabling public health managers to make decisions efficiently. Using artificial neural networks, it was possible to create a classifier model that could show which variables are related to the efficiency in Primary Care and which lead to inefficiency. Moreover, it was used the NICeSim simulator as a tool to evaluate the behavior of each variable identified as relevant to the efficiency in Primary Care of cities. The results demonstrate that the created model was superior to previously proposed models. Furthermore, our model has been demonstrated to be very effective in identifying variables that affect Primary Health. The created model shows that factors, such as illiteracy and welfare programs, considerably affect the efficiency of health care, reinforcing the argument that the focus of the public policies should be dealt in an intersectoral way, improving the factors that positively influence the population health.
\end{abstract}

Keywords: Artificial neural networks; Technology for management in public health; Efficiency.

\section{Resumo}

Os determinantes sociais da saúde são relevantes nas principais estratégias da Atenção Primária à Saúde. No entanto, sabe-se das dificuldades do setor saúde em superar os fatores que interferem negativamente na saúde da população. Assim, objetivou-se criar um modelo computacional para apresentar em detalhes os fatores que de alguma forma estão relacionados à Atenção Primária à Saúde, possibilitando aos gestores de saúde pública a tomada de decisões de forma eficiente. Utilizando redes neurais, foi possível criar um modelo de classificador que pudesse mostrar quais variáveis estão relacionadas à eficiência na Atenção Básica e quais levam à ineficiência. Os resultados demonstram que o modelo criado foi superior aos modelos já utilizados, uma vez que mostrou maior precisão na localização das variáveis que afetam a Saúde Primária. Concluiu que fatores como analfabetismo e programas de bem-estar afetam consideravelmente a eficiência dos cuidados de saúde.

Palavras-chave: Redes neurais; Tecnologia para gestão em saúde pública; Eficiência. 


\begin{abstract}
Resumen
Los determinantes sociales de la salud son relevantes en las principales estrategias de Atención Primaria de Salud. Sin embargo, se conocen las dificultades del sector de la salud para superar los factores que interfieren negativamente con la salud de la población. Por lo tanto, su objetivo fue crear un modelo de computadora para presentar en detalle los factores que de alguna manera están relacionados con la Atención Primaria de Salud, permitiendo a los gerentes de salud pública tomar decisiones de manera eficiente. Utilizando redes neuronales, fue posible crear un modelo clasificador que pudiera mostrar qué variables están relacionadas con la eficiencia en Atención Primaria y cuáles conducen a la ineficiencia. Los resultados demuestran que el modelo creado fue superior a los modelos que ya se utilizaron una vez que mostraron una mayor precisión en la ubicación de las variables que afectan la salud primaria. Concluyó que factores como el analfabetismo y los programas de asistencia social afectan considerablemente la eficiencia de la atención de la salud.
\end{abstract}

Palabras clave: Redes neuronales; Tecnología para la gestión en salud pública; Eficiencia.

\title{
1. Introduction
}

The Primary Health Care (PHC) is considered the preferred gateway to the Brazilian Unified Health System (Sistema Único de Saúde - SUS), promoting health, prevention of diseases and their complications, as well as recovery and rehabilitation. In addition, PHC is considered an organizational model of health systems not only in Brazil but in several countries (Macinko et al., 2007). According to Junqueira et al. (2009), the health-disease process has not only a biological dimension but also incorporates the psychological, social, historical, environmental, and economical dimensions which makes necessary to develop intersectoral and interdisciplinary actions in PHC.

Observing the complexity of the factors related to the population health, the dialogue among the sectors is necessary in order to make possible the articulation of actions that allow PHC to become a full-organization strategy based on health as a universal right and a fair and solidarity institute as designed by the Ministry of Health (Göttems; Pires, 2009).

The Pan American Health Organization (PAHO) reaffirms the need for renewal of PHC, considering that this would be a condition for reaching the Millennium Development Goals, which are: to end hunger and poverty; basic and quality education for all; gender equality and empower of women; to reduce child mortality; to improve maternal health; to combat HIV/AIDS, malaria, and neglected diseases; quality of life; and respect for the environment (Göttems; Pires, 2009). It is known that the improvement of the population health still depends on socioeconomic, environmental, and cultural factors as well as on the resoluteness of the health system in unknown proportions. These are the target factors of synergistic public policies which are part of the agenda of legislators and decision makers in the political and strategic level. Therefore, it is reasonable to assume that they should be the subject of investigation of health public policies (Giovanella et al., 2009).

In this sense, this study had the following investigative question: what factors affect the performance of PHC and in what proportions are they able to determine its effectiveness? Answering this question, these factors could be conducted from the perspective of a health management integrated to the most relevant areas for the development of Primary Health Care in Brazil.

In order to respond to the investigative inquiry, this study used artificial neural networks to build a classifier that relates external variables to the efficiency in PHC, and applied the InfoGain method to determine which variables influence the PHC. BWe also checked the sensitivity of the health performance variable to the change of the conditioning variables.

Thus, the distinction of this work is to apply a methodology that presents a high degree of accuracy in its predictions and is able to build a generalized model that could be implemented in other cities. 


\section{Theoretical Background}

\subsection{Development of Health Promotion and Intersectoriality}

Health promotion consists of actions directed to transform people's behaviors focusing on their lifestyles and locating them at the heart of the family and at the cultural environment of their communities (Buss, 2002).

That health promotion as a new concept of international health emerged in the mid-1970s as a result of the debate of previous decade regarding the social and economical determinants of health and the formulation of a conception not focused on the disease, highlighting the Canadian movement developed from the "Lalonde Report: A new perspective on the health of Canadians", in 1974 (Heidmann et al., 2006).

The 1974 Lalonde Report was the starting point of modern health promotion in Canada, being the first official document to receive the designation of health promotion (Becker, 2001).

The Lalonde Report has affected the health policies of many countries such as England and the United States and has based the adjustment of a new paradigm formalized in the Soviet Union at the International Primary Health Care Conference in Alma-Ata in 1978 with the proposal of Health for All in 2000 and the Primary Health Care Strategy (Heidmann et al., 2006).

Hence, over the 70's and 80 's, the evidence of the relationship between living conditions, prosperity, and good educational level has increased creating conditions for the organization of the First International Conference on Health Promotion in 1996 in Ottawa, Canada, supported by WHO, Ministry of Health and Welfare of Canada and Canadian Public Health Association.

The Ottawa Charter for Health Promotion, a key milestone in the history of public health, adopted as basic prerequisites for health: peace, education, housing, empowerment, stable ecosystem, natural resources defense, and equity (Becker, 2001).

The Ottawa Charter states that the health promotion seeks to reduce the differences in the health status of the population and to provide equal opportunities and resources so that every individual can take care of his/her own health (Brasil, 2000).

Therefore, for these actions to be carried out, they must be on the agenda of governments as priorities leading to health promotion policies.

There are two policy approaches in promoting health. In the first one, health policy involves investments in sectors and the treatment of a specific health problem. It deals with health promotion and prevention in the field of public health and requires involvement of other sectors, which may be represented by agents from the social welfare, industry, education, economy and community sectors as an example (Andrade, 2004).

The second approach relates to healthy public policy, which is characterized by an explicit concern for health and equity promoted by several areas and with a joint responsibility for the impact on health.

The main difference compared to the first approach is that this policy does not arise from a specific health problem but from any issue, for example, economy, traffic, or safety. In this view, it is essential to integrate health concerns in the decision-making process of other sectors such as environment, labor, transportation, housing, and others which affect the health status of a population. Thereby, the notion of healthy public policy is strongly linked to the construction of intersectoral public policies (Andrade, 2004).

\section{Methods}

\subsection{Data collection}

For this work, secondary data on socioeconomic and health conditions of 781 cities of Minas Gerais was collected. The following data were collected electronically on official websites of the Ministry of Health: the Health Facilities Database 
(Cadastro de Estabelecimentos de Saúde - DATASUS), the National Health Fund, and the Firjam Index and Minas Gerais Index of Social Responsibility (Índice Mineiro de Responsabilidade Social - IMRS).

The data collection was processed in two ways: first, we identified variables that could be used in creating an efficiency ratio; second, we collected the socioeconomic and health variables that could have an impact on the performance of primary health care.

\subsubsection{Variables for determining efficiency ratio}

The technical efficiency ratio was generated using Data Envelopment Analysis (DEA) in order to check the optimization level of the PHC resources. For this purpose, the following variables were used:

Inputs: resource of primary care; per capita number of community workers by city; per capita number of basic health units installed by city; per capita number of Family Health Strategy teams deployed by city.

Outputs: percentage of pregnant women over 20 years old by city; live births whose mothers have attended seven or more prenatal visits; average immunization coverage; proportion of Non-Sensitive Ambulatory Care Conditions hospitalizations among population 1-5 years old; proportion of Non-Sensitive Ambulatory Care Conditions hospitalizations of the population aged 60 years or more (these variables are described in detail in Table 1).

The efficiency ratio was built for 781 cities that had complete data for analysis. Each city was classified as efficient and inefficient according to the index, ranging from 0 to 100 which represents the percentage of efficiency, where 100 is the maximum.

The analysis of the DEA, carried out by the author Cabral (2019), conducted using the product orientation since it was aimed to maximize results keeping fixed the amount of resources consumed. CCR (Charnes, Cooper e Rhodes) was the approach used in order to be the most conservative, and therefore the most discriminatory on establishing the efficiency frontier.

\subsubsection{Variables for building the classification model using machine learning}

In order to build a classifier model that could determine which exogenous factors affect PHC efficiency, we collected 48 variables related to economic, social, health, educational, environmental, financial, demographic, security, housing, income, social vulnerability, and social development factors from IDFM (Municipal Development FIRJAN Index) and Minas Gerais Index of Social Responsibility (IMRS) of 781 cities with the efficiency ratio.

After selecting the attributes, seven variables were considered relevant to compose the model. 
Table 1 - Origin of the variables used in the study.

\begin{tabular}{|c|c|}
\hline Employed variables & Source \\
\hline $\begin{array}{l}\text { Illiteracy rate: Ratio of the number of people aged } 15 \text { or older who have not reached four years of } \\
\text { schooling and the total population in this age group multiplied by } 100 .\end{array}$ & IMRS, 2011. \\
\hline $\begin{array}{l}\text { Population density: ratio between the number of children aged } 4 \text { and } 5 \text { years old and the total } \\
\text { resident population multiplied by } 100 \text {. }\end{array}$ & IMRS, 2011 \\
\hline $\begin{array}{l}\text { Per capita receipt of Bolsa Familia: Number of people receiving "Bolsa Família" divided by the } \\
\text { total population. }\end{array}$ & IMRS, 2011 \\
\hline $\begin{array}{l}\text { Population assisted by CRAS: Ratio, in percentage, between the number of CRAS and the } \\
\text { expected number of CRAS according to the size of the city and the total number of families } \\
\text { registered in the Single Registry with up to } 1 / 2 \text { minimum wage per capita income in October of } \\
\text { each reporting year. }\end{array}$ & IMRS, 2011 \\
\hline $\begin{array}{l}\text { Population assisted by health insurance: Ratio, in percentage, of the population assisted by } \\
\text { private health insurance and the total population of the city. }\end{array}$ & IMRS, 2011 \\
\hline $\begin{array}{l}\text { Value Added by Public Administration of the city: Value Added corresponding to the gross } \\
\text { domestic value, excluding taxes less subsidies. }\end{array}$ & IMRS, 2011 \\
\hline $\begin{array}{l}\text { Public security: It is a weighted average of rates related to the following indicators: the homicide } \\
\text { rate ( } 20 \% \text { weight); Rate of violent crimes against property ( } 40 \% \text { weight); Inhabitants by civil and } \\
\text { military police officers ( } 15 \% \text { weight); Number of Community Councils of Public Security ( } 15 \% \\
\text { weight); Budget invested in public safety ( } 10 \% \text { weight). The index can vary from } 0 \text { to } 1 \text {, } \\
\text { respectively representing the worst and best situation (weights calculated by IFDM } 2011 \text { which } \\
\text { provided the data on each index). }\end{array}$ & IFDM, 2011 \\
\hline
\end{tabular}

Source: Authors (2015).

It is important to report that, after datapre-processing, 34 cities were excluded because they present noise in the data, i.e., data were proven incorrect. Hence, in the second step, data from 747 cities of Minas Gerais were used.

\subsection{Data Mining}

Data Mining (DM) is a part of the Knowledge Discovery in Databases (KDD) process. The term KDD, formalized in 1989, is used to represent the process of transforming low-level data in high-level knowledge, whereas data mining may be understood as the extraction of patterns or models from observed data (Goebel \& Gruenwald, 1999).

Thereby, according to Fayyad (1996, p. 30): "KDD is a multistep non-trivial, interactive and iterative process to identify understandable, valid, novel and potentially useful patterns from large data sets".

The data discovery process in the database is divided differently by authors in the field. Following the remarks of Fayyad (1996, p. 30), stages of KDD are four: preprocessing, data transformation, pattern discovery, and presentation of results. This process can also be understandable in a simplified form with three steps: preprocessing, data mining, and postprocessing.

Data mining aims to find the knowledge obscured by complex association patterns and large amounts of data. Some important information may be found after processing large amounts of information. Analytical techniques must be used, from 
the most basic ones (descriptive or graphical approaches) to multivariate sophisticated analysis: cluster, regression, and logistic analysis, as well as artificial neural networks and genetic algorithms (Añaña, 2008).

There is an important difference between data mining and statistical techniques, as statistics uses hypothetical standards for verification, while in data mining the data itself is used to discover these patterns. About $5 \%$ of all relations can be found by statistical methods. On the other hand, data mining can discover other $95 \%$ of the remaining relationships previously unknown (Castanheira, 2008).

Several authors in different areas have used data mining as a means of obtaining knowledge. Authors of the health insurance area Marins et al. (2012) worked on the application of machine learning algorithms for data mining on beneficiaries of health insurance plans in the search for hidden information in their databases that would help in making decisions on disease prevention programs. Félix et al. (2013) studied the application of data mining techniques on reproductive traits of swine in animal biology area.

Thus, the application of DM has proven to be a useful tool to extract knowledge in different areas for different problems.

It should be noted that the discovery of knowledge must have the following characteristics: be efficient (accurate), generic (applicable to various types of data, and flexible (easily modifiable). The DM development process involves tasks, methods, and algorithms for extracting new knowledge. Among these tasks, the association, classification, regression, clustering, and summarization stand out (Galvão \& Marin, 2009).

Various techniques may be employed in different tasks, as shown in Table 2.

Table 2 - Data mining techniques.

\begin{tabular}{|l|l|l|}
\hline \multicolumn{1}{|c|}{ Technique } & \multicolumn{1}{|c|}{ Description } & \multicolumn{1}{c|}{ Tasks } \\
\hline $\begin{array}{l}\text { Association Rule } \\
\text { Discovery }\end{array}$ & Establishes a statistical correlation between data attributes and data sets. & Association \\
\hline Decision Trees & $\begin{array}{l}\text { Data ranking based on decision stages and in the separation of classes and } \\
\text { subsets. }\end{array}$ & $\begin{array}{l}\text { Classification } \\
\text { Regression }\end{array}$ \\
\hline $\begin{array}{l}\text { MBR- Model Based } \\
\text { Reasoning }\end{array}$ & $\begin{array}{l}\text { Based on the nearest neighbor method, it matches and compares attributes } \\
\text { to establish similarity hierarchy. }\end{array}$ & $\begin{array}{l}\text { Classification } \\
\text { Segmentation }\end{array}$ \\
\hline Genetic Algorithms & $\begin{array}{l}\text { General methods of search and optimization, inspired by the Theory of } \\
\text { Evolution: in each new generation, better solutions are more likely to have } \\
\text { "descendants". }\end{array}$ & $\begin{array}{l}\text { Classification } \\
\text { Segmentation }\end{array}$ \\
\hline $\begin{array}{l}\text { Artificial Neural } \\
\text { Networks }\end{array}$ & $\begin{array}{l}\text { Models inspired by the physiology of the brain, where knowledge is a result } \\
\text { of the map of neural connections and the relevance of these connections. }\end{array}$ & $\begin{array}{l}\text { Classification } \\
\text { Segmentation }\end{array}$ \\
\hline
\end{tabular}

Source: Adapted from Dias (2008).

The two primary types of the task of prediction are regression and classification, the latter being used in this study.

Several algorithms are applied to the classification task, especially Genetic Algorithms, Bayesian classifiers, Support Vector machines, and Artificial Neural Networks with the backpropagation training technique.

The Artificial Neural Network is a computational technique that builds a mathematical model inspired by the natural neural networks, with capacity for learning, generalization, association, and abstraction. It is best described in the next section for a better understanding of the technique used in this study. 


\subsection{Artificial Neural Networks}

The study of artificial neural networks was partly inspired by the observation of biological learning systems which are built of extremely complex webs of interconnected neurons (Mitchell, 1997).

Artificial neural networks (ANN) have little in common with the real neural networks. Still, they have the ability to solve complex cognitive problems.

The first studies on artificial neural networks were performed by McCulloch and Pitts, Hebb and Rosenblat, between 1940 and 1950. The subsequent progress was gradual and suffered from a lack of efficient training algorithms. The resurgence of artificial neural networks was due to the development in the training of architecture with intermediate layers, known as multilayer perceptron (MLP) (Oliveira, 2007).

This was the result of studies published in the 1980s Rummerlhart e McClelland (1986), which brought a new training method called backpropagation. This new technique brought new life to research on ANNs, wherein MLP with backpropagation was the most successful example.

There are basically two types of network connections in ANNs: the feedforward, in which the signals propagate in only one direction from the input unit, through the intermediate layers to the output; and feedback networks, where the incoming signals can propagate from the output of any neuron to the input in another neuron (Zampieri, 2006).

There are many ANN models that can be divided into two groups: those with or without supervised training.

In this paper, we used the supervised method of multilayer perceptron neural networks with the logistic activation function to generate probabilities. The architectureis feed-forward with the training method backpropagation.

Several researchers have used multilayer perceptron neural networks in different areas with satisfactory results with the application of this methodology, such as studies in the areas of industrial automation automation (Stivanello; Gomes, 2006), marketing (Añaña et al., 2008); environmental engineering (Zanetti et al., 2008); finance (Coelho et al., 2008); electrical engineering (Fanucchi et al., 2013); agricultural researches Andrade et al., 2013); and health management (Rosas et al., 2013).

In this work, the method of multilayer perceptron neural networks was used for the task of classification of cities with regard to their efficiency in Primary Health Care.

Classification is one of the main applications that artificial neural networks are able to perform. The aim is to associate a category of a finite universe to an object.

Artificial neural networks for classification were employed by researchers as Andrade (2012) and Ventura (2012), who claim to find more satisfactory results with the use of this methodology than with others proceodures (discriminant analysis, cluster analysis, and logistic regression) routinely used in their areas for achieving similar goals.

Thereby, in order to obtain accurate results for the problem-question of this study, we used ANNs for classification. The next section approaches the data processing and the analysis of results.

\section{Processing and Analysis of Results}

For this study, the instances were dichotomously classified: 0 representing the inefficient class and 1 the efficient class. The classes have been set according to the values of PHC efficiency ratio. Cities with ratio lower or equal to 0.549 were classified as inefficient (0) in this study, while the cities that presented values equal to or greater than 0.55 were classified as efficient (1).

This paper adopted the following four-step procedure to achieve the proposed objective: 
1) Conversion of available data to an appropriate format: the data were transformed into .arff format which is a necessary step so that data can be processed in the Weka software (Waikato Environment for Knowledge Analysis) used in this study.

2) Preprocessing of the data: in this step, we performed a reduction of dimensionality through attribute selection, which is the process of selecting a subset of the attributes of the instances present in the data set, in order to eliminate irrelevant and/or redundant attributes, leaving those that have strong relationship with the class.

At this stage, the participation of specialists is important for the fusion of the knowledge of the area studied with the mathematical methods in order to extract the best attributes (Siqueira-Batista, 2014). Hence, we used 48 variables related to economic, social, health, educational, environmental, financial, demographic, security, housing, income, social vulnerability, and social development factors which relate to Primary Health Care to some degree.

For selection of attributes, we used CfsSubsetEval which evaluates the value of a subset of attributes considering the individual predictive ability of each resource along with the degree of redundancy among them.

Thus, the following relevant attributes were obtained: public safety; demographic density; per capita receipt of Bolsa Familia; illiteracy rate; proportion of population served by health insurance; population served by CRAS; and Value Added.

After selecting the attributes, the exploration of the ROC (Receiver Operating Characteristics) curve was performed through the threshold selector algorithm together with artificial neural network, using a 10-fold Cross Validation. The following thresholds were tested: $0.5,0.4,0.3$, and 0.2 . For threshold 0.2 , the correctness rate of the positive and negative classes reached $61 \%$ and $79 \%$, respectively; and the accuracy reached 79.6 .

In a first analysis, the generated model was applied in the training set itself, allowing the ranking of instances that were predicted as negative but were positive; thus, we removed those predicted as negative that presented a high probability of being negative - in this case, equal to or above the median of the probabilities of those positive that were predicted negative. A total of 34 instances were removed from the analysis because they presented values that were considered noise in the data.

3) After this step, 631 instances remained in the class 0 and 116 in class 1 . Threshold selector and ANN were again applied varying the probability thresholds. When testing 0.2 and 0.15 , it was noted an intermediate value: 0.18 . This figure showed accuracy equal to 0.90 , which is a good correctness rate.

The Receiver Operating Characteristics (ROC) analysis was introduced in machine learning and data mining as an important tool for evaluation of classification models (Prati; Batista e Monard, 2008). It is particularly useful in areas where there is great disparity among the classes, as in the case of this study, in which $84 \%$ of instances belong to inefficient class and only $15 \%$ compose the efficient class.

Thereby, the performance was evaluated by the ROC curve which showed an area under the curve of 0.90 .

The ROC analysis allows to quantify the predictive power of the model which is proportional to the area under the curve for which the maximum value is 1.0.

4) In this last stage, to assess the individual importance of each attribute, we used the InfoGain as attribute selector. The resulting ranking is presented in Table 1. 
Table 3 - Ranking of variables by InfoGain.

\begin{tabular}{|c|c|}
\hline Ranking & Atributes \\
\hline 1 & Illiteracy rate \\
\hline 2 & Proportion of the population served by health insurance \\
\hline 3 & Per capita receipt of Bolsa Familia \\
\hline 4 & Value Added \\
\hline 5 & Demographic density \\
\hline 6 & Population servedby CRAS \\
\hline 7 & Public security \\
\hline
\end{tabular}

Source: Authors (2015).

In order to assess the consequences of the variation of the variables in the PHC efficiency, we used NICeSim, an open source simulator based on machine learning techniques to support medical research on prenatal and perinatal decision making. According to Cerqueira et al. (2014), the main characteristics of NICeSim are flexibility, since it permits the inclusion and exclusion of variables according to the requirements of a particular study, and dynamism, as it allows the training of a just in time model. Therefore, the system can be improved with new data when they become available.

Also, according to the authors, NICeSim works with two algorithms to build a machine learning model: Support Vector Machine and Multilayer-Perceptron. However, other machine learning algorithms can easily be incorporated to NICeSim for improvement.

Thus, in order to work with the training set that provided the best results in this study, we made a modification in the source code of NICeSim, in which we added the Threshold Selector method with the Multilayer Perceptron classifier as an option of learning algorithm.

Therefore, we analyzed the variation of the first five ranking variables (for presenting an efficiency sensitivity), in order to demonstrate their interference on PHC.

Four initial scenarios were randomly chosen for each variable by NICeSim, with different combinations of variables, i.e., four scenarios were chosen with different values for each variable. The values of the other variables were kept while the variable in question underwent changes in its minimum and maximum values within a $6 \%$ variation range. Variable values were then transformed into a scale with minimum and maximum values ranging between 1 to 16 . Thereby, at the end of the simulation for each variable being analyzed, we obtained a total of 64 scenarios, that is, 320 total different scenarios for the five simulated variables, demonstrating the trend of the variable affecting positively or negatively the efficiency as the scenario changed.

From the analyzes carried out by the simulator, it was possible to notice that the tendency of the rate of illiteracy (Taxa de Analfabetismo - TXA) negatively affects the PHC efficiency of cities, because as the illiteracy rate increases, there is a decrease in efficiency. There is a trend of sharp decrease in efficiency when TXA increases to 5.5 points.

These results corroborate studies of other authors demonstrating the negative influence that illiteracy and poor education exert over health.

Illiteracy has a negative effect on the health of the elderly population, being one of the factors that lead the elderly affected by disease to have complications that result in hospitalizations and readmission (Carboni e Reppetto, 2007).

Moreover, illiteracy makes them more dependent on others to carry out their daily activities which reduces their autonomy and, consequently, their quality of life. 
The study performed by Assis et al. (2009) shows that the poor level of parental education is a social determinant that negatively influences child health. The poor social competence and child behavior problems such as anxiety, attention deficit, and mental disorders are linked to low parental education, among other factors, in addition to the already known correlation between low educational level of the mother and high infant mortality, a major problem still present in Brazil.

The lack of schooling interferes with the health of the population and, therefore, the PHC efficiency. Educational activities aimed at youth and adult literacy should be the focus of attention of managers who seek to improve the health of the population.

The PHC, by itself, is not able to develop these actions. Therefore, it is necessary to establish partnerships with the education sector, in order to achieve a counter reference to forward individuals who demonstrate interest in studying or going back to school but do not know how to or have particular difficulties.

As the coverage of health insurance increases, there is a consequence on the PHC efficiency. Sharp increases are observed in efficiency for values close to $100 \%$ when reaching points 6 and 9 , that is, close to the average of coverage variation. There is also an increase from point 4 , where the scenario showed values close to $100 \%$.

An important value for this variable is point 9 , because from this value a change in the scenario does not change the efficiency, which remains at $100 \%$. So it is understood that the efficiency of the cities can increase, not requiring that the entire population is covered by health insurance for achieving maximum efficiency.

Health services in Brazil present doubled coverage. This is because the country has a public and a private health system. The public one, the Unified Health System (Sistema Único de Saúde - SUS), is funded by taxes, and has universality as its fundamental principle, i.e., it serves the entire population without distinction. The private system, offered mainly through health insurance, is paid by individuals who voluntarily adhere to a plan, or by companies that offer health insurance to their employees, which compulsorily adhere to the plan (Santos et al., 2008; Farias, 2001).

Even when the individual pays for a health insurance, he/she is still covered by SUS, but the use of some public health services decreases, including PHC services. Therefore, in locations where there is greater coverage by health insurance, there is also a reduction in demand for public health services. With a lower demand of Primary Health Care, it increases the possibility of better service to the people who need it, and this fact affects the PHC efficiency in that area.

The health plan coverage positively interferes on PHC efficiency as the plan increases its coverage according to the simulated results. However, it is important to note that PHC focuses on health promotion actions to the entire population, so these results should also be explored in further studies.

Moreover, this trend of increased efficiency must not be generalized to other levels, since in many cases and in other levels of care, individuals are not fully covered by most health plans that deny care to patients mainly in the high complexity level, leading them to resort to SUS to get their treatments (Santos et al., 2008).

Another relevant variable to the efficiency of the cities is the per capita receipt of Bolsa Família of each city.

We could identify a downward trend in the PHC efficiency in scenarios with increased number of people served by the Bolsa Família Program. In scenarios where PHC efficiency was better, i.e., from values closer to $100 \%$, the increase of Bolsa Família grants made the efficiency decrease considerably.

In the first scenario, where efficiency was low, a small increase of Bolsa Família grants made efficiency increase to the point 6.5. After that point, it decreases, keeping constant all other variables.

The Cash Transfer Programs are an alternative to the reduction of poverty and social inequality found in many countries. These programs, according to Silva (2005), consist of a direct cash transfer aimed at families and individuals in unfavorable economic situation demanding, in return, some conditions, particularly in health, education and work fields in order to develop and empower beneficiary families. 
In Brazil, the Bolsa Família Program (PBF) has been deployed in an attempt to reduce poverty between generations, removing people from levels below and on the edge of the poverty line.

The PBF, whose operations focus on the 16 million Brazilians with per capita income lower than $\mathrm{R} \$ 77.00$ per month, is based on ensuring minimum income for this population. The transferred amount varies according to family size, age of its members, and their income. There are specific benefits to families with children, young people under 17, pregnant women, and nursing mothers (Ministério do Desenvolvimento Social e Combate à Fome, 2014).

According to Oliveira et al. (2008), PBF allows the rise of the education level, improvement of nutritional indicators, the growth of per capita income as well as the increase of life expectancy of the population.

PBF is intended to low-income families. Thereby, the program presents a negative correlation with primary care efficiency, not because it is an adverse factor to the population's quality of life, but because it is linked to the cities with the highest number of poor people who need welfare programs and health care from the public sector (Soares et al., 2006).

It was concluded that a overcrowded Primary Health Care is possibly caused by the high demand for primary care, which occurs by individuals who do not have conditions to take care of health in private clinics or have health plans and need to use the primary health care services to meet the conditions of the program. However, to confirm that statement, in-depth studies should be conducted.

The fourth variable in the ranking is the Value Added, which showed a tendency to increase the PHC efficiency.

It was found that the PHC efficiency of cities increases as the Value Added rises. This occurred in all simulated scenarios, demonstrating that, even in different conditions, the greatest Value Added in the cities is important for PHC efficiency.

The Value Added (VA) is the result of economic movement (addition of wealth) of the city, i.e., it results from the generation of wealth, disengaged from the city collection of ICMS (Tax on Circulation of Goods and Services) but under the city scope (Secretaria da Fazenda, 2009).

The value added reflects the amount of economic value that the public authority can add to society (Bonacim et al., 2008). Thus, through VA it is possible to assess the efficiency of public administration since the return provided to society by the use of public resources can be verified (Slomski, 2001).

The fifth-ranked variable was population density, which proved to be positively related to the efficiency for most scenarios, with small negative variations in the scenarios where efficiency rate started close to $65 \%$.

According to Neri e Soares (2002), there is an increasing trend in demand for health services as the population density increases, a fact that can be partly explained by the lack of such services in rural areas and areas of lower population density. This demonstrates a lag of health services in rural areas. Thereby, it is necessary to expand services to rural areas that often lack rural health units installed or mobile units that may lead to health promotion in remote locations where there is low population density.

The sixth-ranked variable was the ratio between the number of CRAS - Social Assistance Reference Center installed and expected, depending on the size of the city and the total number of families registered in the Single Registry with up to $1 / 2$ minimum wage per capita income, i.e., the number of CRAS compared to the number of units that should exist to offer the assistance support services to the poor communities.

The CRAS is a decentralized state public unit of social welfare policy, responsible for the organization and delivery of basic social protection services of the Unified Social Assistance System (Sistema Único de Assistência Social - SUAS) in areas of vulnerability and social risk of cities and the Federal District. Due to its reach in several regions in the national territory, it is characterized as the main SUAS gateway, i.e., it is a unit that provides access for a large number of families to safety net and social assistance (Ministério do Desenvolvimento Social e Combate à Fome, 2015). 
Therefore, it is important the existence of good coordination between the CRAS and PHC in order to achieve a balance that is satisfactory to both, ensuring the best possible living conditions and health care to the population.

The last-ranked variable was public safety. This subject is always related to the violence intensely present in Brazil, which is reflected in a number of victims who need monitoring and treatment of the health sector.

Violence is related to health since it affects the quality of life of the human being: "Violence is, above all, a social issue and, therefore, it is not an object itself of the health sector. It becomes an issue of this field; due to the impact it makes on the quality of life for the physical, mental, and moral injuries it entails" (Minayo, 2004, p. 646).

According to the World Health Organization (WHO), the consequences of violence converge on health care that must provide emergency services, specialized treatments, physical and psychological rehabilitation, and social assistance to victims directly and indirectly affected by violence (OMS, 2002).

In this sense, it is observed that the increase of public safety may positively interfere to the improvement of PHC efficiency, since it affects the living conditions of the population and its quality of life.

It is noteworthy that the CRAS and public safety variables were not simulated for presenting high sensitivity to changes within the set of variables analyzed.

\section{Conclusion}

In this study, we found the variables that are more relevant to the PHC efficiency, especially illiteracy, proportion of families served by health insurance, and people receiving Bolsa Familia. Moreover, it was possible to calculate the point where the city efficiency changed between the minimum and maximum values for each variable.

Hence, it can be seen that the results corroborate the literature presented throughout this paper about the variables analyzed, in addition to providing important information about value added, a variable not commonly identified as influential to Primary Care efficiency.

While pointing out the value added as a factor that influences the efficiency of Primary Health Care, it is observed that there is a relationship between the efficiency of municipal management and PHC efficiency, which demonstrates the importance of good management for efficiency in health. When making such analysis, it is not the goal to withdraw from PHC its own ability or responsibility to be efficient, but clearly demonstrate that health, in its broad conception, covers factors that are not managed solely by PHC.

This study sought to demonstrate the relevance of intersectoral action, in which sectors work focused not only individually, but to benefit all sectors involved as well as bring more efficient solutions for the population.

From the analysis, it was concluded that external factors can interfere with PHC efficiency, requiring greater effort of public management in developing areas such as education, social assistance, public security, and there also must be a concern to develop these areas in a cross-sectoral manner, since the public health alone cannot solve all the problems that may interfere with health and people's quality of life.

It is worth mentioning that the model created with the ANNs of this study can work as a predictor of PHC efficiency, being able, with the simulator, to diagnose the main factors that affect the efficiency, supporting the decision making process aiming an improved efficiency.

For future studies, it is worth exploring the various possibilities that neural networks can offer for the diagnosis of complex problems involving a large amount of data in the area of public health. 


\section{References}

Añaña, E. D. S., Vieira, L. M. M., Petroll, M. D. L. M., Petersen-Wagner, R., \& Costa, R. S. (2008). As comunidades virtuais e a segmentação de mercado: uma abordagem exploratória, utilizando redes neurais e dados da comunidade virtual Orkut. Revista de Administração Contemporânea, 12(SPE), 41-63.

Andrade, L. O. M. D. (2004). A saúde e o dilema da intersetorialidade.

Andrade, Livia Naiara et al. (2013). Aplicação de redes neurais artificiais na classificação de áreas cafeeiras em Machado-MG. Coffee Science, 8(1), 78-90.

Assis, S. G., Avanci, J. Q., Oliveira, R. de V. C. (2009).Desigualdades socioeconômicas e saúde mental infantil. Rev. Saúde Pública, 43(1), 92-100,

Becker, D. (2001). No seio da família: amamentaçäo e promoçäo da saúde no Programa de Saúde da Família (Doctoral dissertation).

Brasil. (2000). Ministério da Saúde. Secretaria de Políticas de Saúde. O trabalho do Agente Comunitário de Saúde. Brasília.

Brasil (2014). Bolsa Família. Ministério do Desenvolvimento Social e Combate à Fome. Recuperado de: 〈http://www.mds.gov.br/bolsafamilia〉.

Brasil.(2009) Ministério do desenvolvimento social e combate à fome. Orientações Técnicas Centro de Referência de Assistência Social - CRAS. Brasília. <http://sistemas.fecam.org.br/SUAS/publicacoes/11-\%20Cras\%20Orienta\%C3\%A7\%C3\%B5es\%20T\%C3\%A9cnicas.pdf>.

Bonacim, C. A. G., de Araújo, A. M. P., \& de Souza Miranda, C. (2008). Modelo conceitual de mensuração do resultado econômico em entidades públicas. ABCustos, 3(2).

Buss, P. M., Buss, P., \& Buss, P. M. (2002). Promoção da saúde da família.

Cabral, K. F. D., Ferreira, M. A. M., Batista, R. S., \& Cerqueira, F. R. (2019). Atenção primária à saúde: uma análise a luz da eficiência técnica dos recursos no Estado de Minas Gerais. Revista de Gestão em Sistemas de Saúde, 8(2), 137-150.

Castanheira, L. G. (2008). Aplicação de técnicas de mineração de dados em problemas de classificação de padrões. Dissertação de Mestrado em Engenharia Elétrica - UFMG.

Cerqueira, F. R., Ferreira, T. G., de Paiva Oliveira, A., Augusto, D. A., Krempser, E., Barbosa, H. J. C., \& Siqueira-Batista, R. (2014). NICeSim: an opensource simulator based on machine learning techniques to support medical research on prenatal and perinatal care decision making. Artificial intelligence in medicine, 62(3), 193-201.

Coelho, L. D. S., Santos, A. A. P., \& Costa Jr, N. C. A. D. (2008). Can we forecast Brazilian exchange rates? Empirical evidences using computational intelligence and econometric models. Gestão \& Produção, 15(3), 635-647.

Carboni, R. M., \& Reppetto, M. Â. (2007). Uma reflexão sobre a assistência à saúde do idoso no Brasil. Revista Eletrônica de Enfermagem, 9(1).

Dias, M. M. (2002). Parâmetros na escolha de técnicas e ferramentas de mineração de dados. Acta Scientiarum. Technology, 24, $1715-1725$.

Fayyad, U., Piatetsky-Shapiro, G., \& Smyth, P. (1996). From data mining to knowledge discovery in databases. AI magazine, $17(3)$, $30-37$.

Farias, L. O. (2001). Estratégias individuais de proteção à saúde: um estudo da adesão ao sistema de saúde suplementar. Ciência \& Saúde Coletiva, 6, 405416.

Fanucchi, R. Z., Oleskovicz, M. A. R. I. O., \& Barbosa, D. A. N. I. E. L. (2013). Análise da Detecção de Faltas de Alta Impedância Utilizando Redes Neurais Artificiais com Topologias Baseadas em Perceptron Multicamadas e Redes RBF. Simpósio Brasileiro de Automação Inteligente (SBAI), Fortaleza.

Felix, L. F. C., Maria das Graças, J. M., \& Pontes, A. N. (2013). Aplicação das técnicas de mineração de dados sobre as características reprodutivas de suínos: estudo de caso de uma granja do estado de São Paulo. Reverte-Revista de Estudos e Reflexões Tecnológicas da Faculdade de Indaiatuba, (11).

Galvão, N. D., \& Marin, H. D. F. (2009). Técnica de mineração de dados: uma revisão da literatura. Acta Paulista de Enfermagem, 22(5), 686-690.

Giovanella, L., Mendonça, M. H. M. D., Almeida, P. F. D., Escorel, S., Senna, M. D. C. M., Fausto, M. C. R., \& Teixeira, C. P. (2009). Saúde da família: limites e possibilidades para uma abordagem integral de atenção primária à saúde no Brasil. Ciência \& Saúde Coletiva, 14(3), 783-794.

Göttems, L. B. D., \& Pires, M. R. G. M. (2009). Para além da atenção básica: reorganização do SUS por meio da interseção do setor político com o econômico. Saúde e Sociedade, 18, 189-198.

Goebel, M., \& Gruenwald, L. (1999). A survey of data mining and knowledge discovery software tools. ACM SIGKDD explorations newsletter, 1(1), $20-33$.

Heidmann, I. T., Almeida, M. C. P. D., Boehs, A. E., Wosny, A. D. M., \& Monticelli, M. (2006). Promoção à saúde: trajetória histórica de suas concepções. Texto \& Contexto-Enfermagem, 15(2), 352-358.

Junqueira, T. D. S., Cotta, R. M. M., Gomes, R. C., Silveira, S. D. F. R., Siqueira-Batista, R., Pinheiro, T. M. M., \& Melo, E. M. D. (2009). Saúde, democracia e organização do trabalho no contexto do Programa de Saúde da Família: desafios estratégicos. Revista Brasileira de Educação Médica, $33(1)$, $122-133$.

Klemettinen, M., Mannila, H., \& Toivonen, H. (1997, September). A data mining methodology and its application to semi-automatic knowledge acquisition. In Database and Expert Systems Applications. 8th International Conference, DEXA'97. Proceedings (pp. 670-677). IEEE.

Macinko, J., Montenegro, H., Nebot Adell, C., \& Etienne, C. (2007). Grupo de trabajo de Atención Primaria de Salud de la Organización Panamericana de la Salud. La renovación de la atención primaria de salud en las Américas. Revista Panamericana Salud Publica, 21(2/3), 73-84. 
Research, Society and Development, v. 10, n. 1, e31010111740, 2021 (CC BY 4.0) | ISSN 2525-3409 | DOI: http://dx.doi.org/10.33448/rsd-v10i1.11740

Marins, O. L. F., Barros, E. F., Romão, W., Constantino, A. A., \& Souza, C. L. (2012). Aplicação de algoritmos de aprendizagem de máquina para mineração de dados sobre beneficiários de planos de saúde suplementar. Journal of Health Informatics, 4(2).

McClelland, J. L., Rumelhart, D. E., \& PDP Research Group. (1986). Parallel distributed processing. Explorations in the Microstructure of Cognition, 2, 216271.

Mitchell, T. M. (1997) Machine learning. McGraw-Hill.

Minayo, M. C. D. S. (2004). A difícil e lenta entrada da violência na agenda do setor saúde.

Neri, Marcelo, Soares, Wagner. (2002). Desigualdade social e saúde no Brasil Social inequality and health in Brazil. Cadernos de Saúde Pública, 77-87.

Oliveira, I. C., de Lima, K. F. P., \& UEA, A. G. H. (2010). O programa bolsa família e o índice de desenvolvimento humano na cidade de Manaus.

Oliveira, M. A. D. (2007). Aplicação de redes neurais artificiais na análise de séries temporais econômico-financeiras (Doctoral dissertation, Universidade de São Paulo).

Organização Mundial da Saúde. (2002). Relatório mundial sobre violência e saúde.

Prati, R. C., Batista, G. E. A. P. A., \& Monard, M. C. (2008). Curvas ROC para avaliação de classificadores. Revista IEEE América Latina, 6(2), $215-222$.

Rosas, M. A., Bezerra, A. F. B., \& Duarte-Neto, P. J. (2013). Uso das redes neurais artificiais na aplicação de metodologia para alocação de recursos da saúde. Revista de Saúde Pública, 47(1), 128-136.

Selau, L. P. R., \& Ribeiro, J. L. D. (2009). Uma sistemática para construção e escolha de modelos de previsão de risco de crédito. Gestão e produção. São Carlos, SP. Vol. 16, n. 3 (jul./set. 2009), 398-413.

Stivanello, M. E., \& Gomes, P. C. R. (2006). Inspeçao visual industrial automatizada por análise de forma com descritores de fourier e redes neurais artificiais. Anais do XV Seminco,

Siqueira-Batista, R., Gomes, A. P., Maia, P. M., Costa, I. T. D., Paiva, A. O. D., \& Cerqueira, F. R. (2014). Modelos de tomada de decisão em bioética clínica: apontamentos para a abordagem computacional. Revista Bioética, 22(3), 456-461.

Santos, I. S., Ugá, M. A. D., \& Porto, S. M. (2008). O mix público-privado no Sistema de Saúde Brasileiro: financiamento, oferta e utilização de serviços de saúde. Ciência \& Saúde Coletiva, 13, 1431-1440.

Silva, M. O. (2015). Os programas de transferência de renda e a Pobreza no Brasil: superação ou regulação? Revista de Políticas Públicas, 9(1), 251-278.

Soares, F. V., Soares, S., Medeiros, M., \& Osório, R. G. (2006). Programas de transferência de renda no Brasil: impactos sobre a desigualdade.

Slomski, V. (2001). Mensuração do resultado econômico nas entidades públicas: uma proposta. Argos.

Ventura, R. V., Silva, M. A., Medeiros, T. H., Dionello, N. L., Madalena, F. E., Fridrich, A. B., \& Corrêa, G. S. S. (2012). Use of artificial neural networks in breeding values prediction for weight at 205 days in Tabapuã beef cattle. Arquivo Brasileiro de Medicina Veterinária e Zootecnia, 64(2), 411-418.

Zampieri, F. L. L. (2006). Modelo estimativo de movimento de pedestres baseado em sintaxe espacial, medidas de desempenho e redes neurais artificiais.

Zanetti, S. S., Sousa, E. F., Carvalho, D. F. D., \& Bernardo, S. (2008). Estimação da evapotranspiração de referência no Estado do Rio de Janeiro usando redes neurais artificiais. Revista Brasileira de Engenharia Agrícola e Ambiental, 12(2), 174-180. 